\title{
Czech Women's Civic Organising under the State Socialist Regime, Socio-economic Transformation and the EU Accession Period ${ }^{1}$
}

\author{
HANA HAŠKOVÁ* \\ Institute of Sociology, Prague
}

\begin{abstract}
The article describes Czech women's civic organising focused on gender equality and women's rights since the Second World War and explains its character and development in the context of a) the state socialist regime, b) the impact of foreign and international donors on Czech women's civic organising during the socio-economic and political transformation of the first part of the 1990s, and c) the current process of the formalisation of Czech women's civic groups brought about by the Czech Republic's preparation for EU accession. The formalisation of women's civic groups is a process that consists of project-orientation, reform-orientation and the professionalisation of women's civic groups. In the era when the funding of women's civic groups has changed (as a result of EU Eastern enlargement) and the range of national political actors engaged in promoting gender equality has broadened (owing to pressure from the EU), these processes have brought about a shifts in the topics, activities, partnerships and strategies of Czech women's civic groups. These processes have contributed on the one hand to the marginalisation of those topics, activities and strategies previously addressed by some of Czech women's civic groups that do not fit in with the mainstream topics, activities and strategies defined by the EU (and by the EU influenced state). At the same time, however, some channels for having an impact on national decision-making processes have opened up to specific women's civic groups. EU Eastern enlargement paradoxically led to the orientation of women's civic groups towards national rather than supranational lobbying.

Sociologický časopis/Czech Sociological Review, 2005, Vol. 41, No. 6: 1077-1110
\end{abstract}

* Direct all correspondence to: Hana Hašková, Gender and Sociology Department, Institute of Sociology, Academy of Sciences of the Czech Republic, Jilská 1, Prague, Czech Republic, e-mail: Hana.Haskova@soc.cas.cz.

1 The article is based on data and analyses that were collected and made under two international research projects: 'Enlargement, Gender and Governance: The Civic and Political Participation and Representation of Women in EU Candidate Countries' project, co-ordinated by Yvonne Galligan (Queen's University Belfast), and funded by the 5th Framework Programme of the European Commission (see www.qub.ac.uk/egg), and 'Constructing Supranational Political Spaces: The European Union, Eastern Enlargement and Women's Agency' project, coordinated by Joanna Regulska (Rutgers University), and funded by the United States National Science Foundation. In parts two and three of this article, the author uses some of the analyses she made and presented together with her colleagues: A. Kř́žzová, D. Lorenz-Meyer,

(C) Sociologický ústav AV ČR, Praha 2005 


\section{Introduction}

This article describes Czech women's civic organisational activity aimed at promoting gender equality and women's rights since the Second World War, and explains its character in the context of the equality agenda of the state socialist regime, the socio-economic and political transformation of the first part of the 1990s, and the current processes of formalisation that women's non-governmental organisations (NGOs) underwent as part of the Czech Republic's (CR) preparation for accession to the European Union (EU). First, it examines what the effect of the state socialist regime was on women's civic organising aimed at women's rights and the equality of men and women in the region. It concentrates on the role of semi-state women's organising in promoting the equality of men and women in the region and investigates whether there was any independent women's civic organisational activity focused on women's rights and gender equality under the state socialist regime. It goes on to look at the scope and character of women's civic organising during the political and socio-economic transformation after 1989 and examines the impact of foreign donors on women's civic organising in the country during that period. This is followed by a study of the impact of the EU on women's civic organising in the country during the CR's preparations for accession to the EU, which evaluates both its positive and negative aspects for women's civic organising in the country and asks whether the EU accession led Czech women's civic groups to orientate themselves more towards supranational or national bodies in their efforts to promote gender equality and women's rights. The conclusion highlights and summarises the interconnected effects that the processes influencing Czech women's civic organising aimed at the promotion of women's rights and gender equality since the Second World War have had on its current state.

In the article, Czech women's civic groups are referred to as women's NGOs and informal (non-registered) women's civic groups. Civic participation (and specifically women's civic organising) is thus defined not only in terms of participation in formalised NGOs, which are commonly seen as representing civil society in the countries of Central and Eastern Europe (CEE), because they are the prevailing form of civic participation there [e.g. Hann 1996; Sampson 1996], but also in reference to informal (non-registered) groups.

The article is based on analyses of semi-structured expert interviews and focus groups carried out in the CR in 2003-2005. The interviews were conducted with: a) representatives of 37 Czech informal women's civic groups, representatives of NGOs that are members of registers of Czech women's NGOs, and representatives of Czech NGOs that are not members of those registers but have at least one project focusing on gender equality, b) 6 Czech female activists active before 1989 focusing on human rights, and c) 7 representatives of the European Commission. The

L. Simerská (2004) and K. Kapusta-Pofahl and M. Kolářová (2005). The author would like to thank the two anonymous reviewers of the article for their comments, and Karen KapustaPofahl and Alena Kř́žžková for their unofficial comments, all of which contributed to its improvement. 
two focus groups were conducted with 7 representatives of women's NGOs and NGOs that have at least one gender equality project. ${ }^{2}$

\section{Historical background}

As in many other CEE countries, a number of women's organisations and even informal groups were active in Czechoslovakia between the two world wars, with the women's movement dating back to the 19th century. At that time, Czech and Slovak women gained the right to an education and to vote thanks to the persistent and systematic activities of the feminist movement, prominent figures (such as the first President of Czechoslovakia), women's associations, and institutions. ${ }^{3}$ In this situation, where the advancement of women's rights was in the developmental stage, the process was influenced by the onset of state socialism in the country after the Second World War.

\section{The specifics of women's organising under the state socialist regime - the official sphere}

Under state socialism, the 'equal rights of men and women' had to be achieved chiefly through women's economic independence (but without substantial criticism of traditional gender roles within the family). Women's (feminist) associations were referred to as a bourgeois relic [Uhrová 1994]. Soon after the war, the state prohibited the free association of citizens and replaced associations with state-sponsored, state-controlled mass organisations, whose activities and ideas were carefully examined in order to keep them in line with the communist regime. Many existing feminist associations were forced to integrate into one women's organisation - the Czechoslovak Women's Council (CWC). The women's movement thus became less dispersed and more easily controlled. Given the fact that the CWC endorsed ideas that were unacceptable after the communist takeover in February 1948, the communist Czechoslovak Women's Union (CSWU) was established and granted existence as the one and only women's organisation in the country. ${ }^{4}$ However, even the

\footnotetext{
${ }^{2}$ Interview respondents are always quoted with the main topic the NGO focuses on specified, and also usually indicating the location of the NGO and the date it was established and the age of the respondents. However, owing to the fact that permission has not been obtained from all the respondents to quote them other than anonymously (permission was obtained only from some of them), reference to the relevant location, date and age is not always made. ${ }^{3}$ For example, the Women's Production Association (founded in 1871), the Minerva Association for Women's Studies (1890), the Committee for Women's Voting Rights (1905), the Women's National Council (1923) - an umbrella organisation, and others.

${ }^{4}$ According to Potůček (1997), the number of NGOs fell in 1948 from 60000 to 683 . These 683 NGOs were incorporated into the unified National Front. A further decrease occurred in 1970s in reaction to democratisation activities during the Prague Spring of 1968.
} 
CSWU died out after a short period of activity, which was directed at reinforcing state ideology and obtaining women for work in agriculture and industry.

In 1967 the Czechoslovak Communist Party unexpectedly passed a resolution that assembled a constituent convention and revived the CSWU as the only mass women's organisation in the country. An organisation of this type existed in most of the countries of the former Eastern European block [Sloat 2004a: 18]. At the convention, the declaration was made that 'women make up a social group, at whose foundation is not only women's biological difference and maternal function, but also the reality that women's role as mothers has certain social and economic consequences for them' [Uhrová 1994].

In compliance with a federal order of the Republic, national organisations were formed under the CSWU - the Czech Women's Union (CWU) and the Slovak Women's Union (SVU) - and most often they organised cultural and social events, discussions, or ad hoc collective voluntary work at the regional level aimed at improving local facilities. The most active members of the organisation came from the countryside, where the opportunities of cultural and social life were limited in comparison to towns. ${ }^{5}$ The bodies of the CSWU were occupied by female representatives of the Central Committee of the Czechoslovak Communist Party, and at the same time the CSWU made proposals for suitable women's candidates to fill what were puppet-like political bodies with quotas for women. The CSWU officially set the goal of strengthening equality in the creation, implementation and monitoring of government policies, and like the CWU and SWU it was officially allowed to participate in the 'external' observation of legislation relating to women and families. However, according to a statement made by a chairwoman of the CSWU at a convention on 16 June 1989 (several months before the change in political regime), considering the deadlines established for concluding the individual phases in the legislative process, in reality the conditions necessary to really utilise these powers were lacking [Kabrhelová 1989].

No government institutions specialising in the implementation of the equality of women and men existed under the state socialist regime in Czechoslovakia. The issues connected to the position of women in society (mainly in connection to motherhood) were to a certain extent discussed within other governmental bodies. ${ }^{6}$ One of the respondents in the above-mentioned interviews, who in the 1980s had been

5 The fact that a certain part of the activities of CWU came from the actual needs of women and the fact that CWU representatives had the social capital in terms of networking, organisational skills and property resources from the past, might be considered today to be the main reason that the CWU did not die out or lose its whole regional structure after 1989, which was the case of similar organisations in many other countries of the former Eastern European block.

${ }^{6}$ For example, the Federal Ministry of Labour and Social Affairs, Ministry Department for Care of Family and Youth, the government committee for preparation for marriage and parenthood or the government committee for population policies. 
active in the Ministry Department for the Care of Family and Youth, ${ }^{7}$ described the interaction and interconnection between the CWU and the state in the 1980s as follows:

The Czech Women's Union had committees, e.g. the committee for the family and the committee for women's' working conditions. Specifically, the female boss of the Department for the Care of Children and Youth at the Ministry of Labour and Social Affairs, Vlasta Brabicova, was on this committee for family, and actually she very often sent me to the sessions of this committee and it was awkward for me to go to the committee of some sort of NGO [CWU - author's note] and not be a member, so I became one in 1986. I kept going to the committees as a member of the state administration and through this activity the state administration got information from the 'women's movement' [interestingly, 'women's movement' meant CWU in this sentence - author's note]. ${ }^{8}$ For example, what is necessary to do and what measures are necessary to take and also what the pains are....

In this way, according to the interviewee, the activities of the CWU influenced some of the government's pronatal measures of the time:

During the time we created family policies [at the ministry - author's note]. I know that I went around the regions and around the country. In fact, I consulted on the material [legislative measures - note of the author] with these women. And these women had the possibility to say, you know, what they wanted. And I remember that some pronatal measures at that time were created thanks to the Czech Women's Union, and that women, you know, wanted to be freer, to have longer maternity leave, to create for themselves better conditions, that preschool facilities functioned somehow.

Thus, according to the interviewee, the CWU had some impact on some range of policies, mainly connected to motherhood.

\footnotetext{
7 Today, she is an older representative of a women's NGO long in existence with offices in several regions that focuses mainly on work-family issues.

${ }^{8}$ Note that in this quotation the respondent says ' $\mathrm{NGO}^{\prime}$, but she means the CWU, even though it was more a semi-governmental than a non-governmental organisation; also, interestingly, the respondent's reference to the 'women's movement' is in reality again a reference to the CWU. The author here does not agree with the use of the terms 'NGO' and 'women's movement' to describe the character of the CWU before 1989. However, this usage shows the respondent's effort to show the connection between this part (CWU) of the semi-state organisation (CSWU) and real women living in the country. With the same intention, elsewhere in the interview, she also stresses the fact that the CWU (as opposed to the CSWU) criticised police intervention against people protesting against the regime on 11 November 1989, which ultimately led to the change of political regime in the country.
} 


\section{The specific features of women's civic organising under the state socialist regime - the unofficial sphere}

The formation of civic opposition to the state socialist regime and the state started in Czechoslovakia particularly in the late 1960s and in the 1970s. However, women's groups were not formed in the unofficial (underground) civic sphere. Women took part in underground democratisation activities of all kinds along with men, but the issue of human rights and freedoms generally were given primary importance, and women's rights and the equality of men and women were rarely discussed. For example, the issue of women's rights or the equality of men and women rarely came up in the documents drawn up by Charter 77 (Charta 77)..$^{9}$ During its existence, Charter 77 produced over 500 documents addressing issues from a variety of civiclegal and human rights areas. The only issue addressed by Charter 77 explicitly in the context of women's rights was the issue of the sterilisation of Roma women without their informed consent, a practice aimed at reducing the number of children they had [Rakušanová 2003].

Even though some criticism was voiced, for example from Prečan et al. [1997], evaluating the gender relations in the Czech democratisation movement as patriarchal after 1989, our respondents (women active in the democratisation movement before 1989) said that they did not acknowledge gender inequality issues in the movement at that time, as their focus was on human rights and freedoms in general and in their former civic activities the other issues seemed less important. ${ }^{10}$

In sum, under the previous political regime, the second wave of feminism (as a social movement) was missed [Havelková 2002]. Even though some of its issues, such as the right to abortion, publicly available childcare facilities, and women's participation in the labour market, were raised at the state and semi-state levels, they were not raised at the grassroots civic level. Moreover, many other issues, such as domestic violence, sexual harassment, etc., were not on the semi-state or state-controlled media agenda at all. Even though the government signed the international decrees of the International Labour Organisation and the United Nations on the issues of gender equality and discrimination and the Federal Ministry of Labour and Social Affairs drew up periodic reports once every four years on how these issues were being solved there was no civil society group that was able to write and publish 'shadow reports' confronting the governmental ones (in contrast to the situation now).

Historical legacies and past experiences mean that the termination of earlier grassroots women's civic organising, and then the character and activities of the

${ }^{9}$ Charter 77 was the most visible part of the democracy movement in Czechoslovakia. It was a loose association of people, a democratic opposition described by its activists as a conglomerate of informal relations and social networks. From its founding, Charter 77 was persecuted by the regime and was disparaged in the press without familiarising the public with its manifesto, which had about 1900 signatories in total, of which $19 \%$ were women.

${ }^{10}$ However, one of our respondents became a well-known feminist after 1989. She stressed the influence of Western feminists after 1989 on her post-1989 activities. 
state and the semi-state organisations that were assigned to deal with the equality of men and women during the state socialist regime in the country, are related to the character of women's civic organising focusing on women's rights and gender equality that emerged in the region after 1989.

\section{Women's civic organising during the first half of the 1990s}

In the civically and politically mobilised atmosphere of 1989 and the early 1990s, many civic and political initiatives, groups and organisations were created in all the countries of the former Eastern European block. ${ }^{11}$ Analyses of current women's organising in the region have already reflected on the fact that women became more active in civic associations rather than they did in formal politics or large movements after the change of the political regime [Gal and Kligman 2000a, 2000b; Kay 2000; Lang 1997]. ${ }^{12}$ About 70 women's civic groups existed in the CR already by the early 1990s. Like other countries in the region, women's civic groups were founded as interest or self-help groups; groups oriented around social problems, professional organisations, branches of international organisations, and women's groups connected to political parties, churches, social movements and the academic scene [Čermáková et al. 2000]. In some cases they were founded by women who had emigrated from the country during the communist regime and returned after 1989. Many of the groups were supported on the basis of individual friendships with foreign feminists. Some were established as a result of pressure exerted by nonCzech/international organisations on similarly oriented organisations in the CR (e.g. the pressure of foreign Catholic women's organisations on representatives of the Czech Catholic Church to establish its own women's group).

As in other countries, these groups have addressed a variety of issues, like the issues of women in the labour market and the public sphere, violence against women and trafficking in women, reproductive health and social services in child care, minority women's issues (e.g. Roma women and lesbian women), environmental and eco-feminist issues, and issues of increasing gender sensitivity, awareness and education among the public [Marksová-Tominová 1999; Sloat 2005]. Some have focused mainly on providing services to special groups of women (single mothers, victims of domestic violence, prostitutes, etc.) and thus substitute for the state where it has gaps in the provision of services. Others have focused especially on

11 According to Potůček [1997], approximately 20000 civic associations were registered in 1992 in Czech society. Four years later, the number had reached 37000 organisations. After a legislative amendment introduced in 1997, the number fell to 55 foundations, 695 endowment funds, and 560 public benefit corporations [Potůček 1997].

12 This was also evident in the huge decrease in the number of women representatives in the parliaments of all the CEECs after quotas for political participation were abolished and after the real decision-making power of parliaments increased (no longer being 'puppet' parliaments) in the region at the beginning of the 1990s [Sloat 2004a, 2004b]. 
raising awareness and promoting legislative changes in the area of gender equality and women's rights.

Representatives of women's civic groups have also varied in their ideological approaches and in the terms they use to characterise their activities: there are many representatives of civic groups included in the databases of Czech women's civic groups (created by Czech women's civic groups) that do not consider themselves to be feminists, some do not consider their goals to be political, and a small part of them have also denied that their organisations are women-centred. The fear of the feminist label has been connected to the reluctance on the part of society in general to support any kind of 'ism's' from the past [Einhorn 1996; Goldman 1996; Gal and Kligman 2000a], and to a further fear of being labelled a 'western-like', 'radical' 'man-hater' throughout the CEE region [Sloat 2005]. ${ }^{13}$ The fear of being labelled as politically oriented is linked to the notion of 'dirty corrupt party politics' that derives from the historical legacy of the entire region [Sloat 2005]. The fear of being labelled 'pro-woman' is mainly associated with a fear of being accused of discrimination again men and being unjust and with the notion that the position of women in society should be advanced by men and women together (neither by women's groups nor by means of positive discrimination, which were both discredited in the region's past experiences): For example:

\begin{abstract}
Maybe somebody does label us as feminists, but we aren't! I think that feminism is definitely, definitely not the right term. Our activities have nothing to do with feminism. I'd say that we are an organisation that aims to help all of society, not just women. You see - we speak about the equality of men and women. Not just women come to our office, we also co-operate with organisations in which men also work, men and women together. So, not feminism, I would not like anybody to call me a feminist, definitely - I am not a feminist at all.... ${ }^{14}$
\end{abstract}

This representative then went on to say that they currently 'want to prepare young women for entering into politics' but that their 'organisation is apolitical'. This view is based on the fact that many representatives of Czech women's civic groups understand 'political orientation' in terms of party politics.

A representative of another NGO, however, argued the opposite:

Of course our activities are political. Yes. Well, we have one leaflet where it was written that we are apolitical, but that was a mistake, that was based on a former misunderstanding... [Our

13 The disassociation from 'Western-like feminist radicalism' exists as a widespread preconception in the region without anyone having the ability to name a concrete example of the radical groups from whom it is necessary to distance oneself.

14 This statement was made by a more elderly representative of a regional office of one longexisting women's NGO with offices in several regions focusing mainly on work-family issues. Interestingly, the main representative of the entire NGO, a person of about the same age, argued that the NGO is politically and feminist oriented. 
activities] are feminist as well...we focus on women, our activities are for women and relate to women... the term [feminism] has a negative connotation in the population, it is an invective, it does not have clear definition'. ${ }^{15}$

In the first half of the 1990s, formally registered women's NGOs and informal civic groups relied heavily on voluntary work and informal networks. With several exceptions of special groups connected to churches or political parties, and with the exception of the Czech Women's Union (with regional offices established during the previous political regime),women's civic groups were very small in size. They consisted of about ten or twenty people, with, for example, only two active members. Such a situation resulted in a number of the women's NGOs that had been founded in the first half of the 1990s breaking up after the departure of those few active leaders who could then not be replaced. Today, only one-third of the currently registered women's NGOs are organisations that were established in the first half of the 1990s.

Funding was derived from individual arrangements. Through personal contacts it was often acquired from private foundations, and bilateral development assistance could be obtained from different countries in 'Western' Europe, the US and Canada, and also from international organisations. Foreign and international funding bodies were the only significant funding bodies for Czech women's civic groups. Funding from these sources tended to be flexible in terms of how it was to be used. There was project funding, but also funding that could be used for the development of the organisation itself. There were also many cases of long-term all-inclusive funding from foreign or international 'parent organisations' for the development of local branches of those international or foreign organisations.

In the first half of the 1990s, however, women's civic groups still lacked experience, expertise, wider recognition, and contact with state bodies, politicians and other social actors. The latter did not recognise women's rights and gender equality as political issues, and the Czech media and society in general were not gender sensitive [Osvaldová 2004; Čermáková et al. 2000]. There was even a rise in gender-conservatism at the beginning of the 1990s in the CEE region [Hašková 2005]; this was also shown in studies reflecting on the empowerment of male economic actors as citizens under the newly applied paradigm of the neo-liberal market in the region, and on the negative effects on women in the region of the post-1989 withdrawal of social entitlements [e.g. Einhorn 2005]. ${ }^{16}$

15 This statement was made by a middle-aged representative of an eco-feminist NGO that was located in Prague and was founded in the second half of the 1990s, but whose office has now closed.

${ }^{16}$ This was also well documented in statements made in the media and on the political scene in many CEECs. In the CR, when the country began encountering its first problems with unemployment, many politicians discussed abolishing the 'mandatory work rule' and deploying the concept of freedom and freedom of choice in reference to the 'voluntary' and 'natural' re- 
Since the beginning of the 1990s, women active in the newly created women's civic groups have distanced themselves from the Czech Women's Union and have been wary of Western feminists and feminisms too, while they have also varied among themselves in terms of their topics, ideologies and organisational structures. In the first half of the 1990s there was no common issue that united them (the way the topic of abortion works in Poland [Fuszara 2005]). Instead their activities came across as primarily fragmented and disjointed. Both longer-term and short-term coalitions and umbrella women's NGOs developed mainly around a thematic focus (e.g. violence on women; childcare), or around a religion ${ }^{17}$ or a political orientation, ${ }^{18}$ and also in relation to the foundation date, that is, either before or after 1989. Thus, for example, the CWU was in several cases explicitly excluded from the range of possible members in a coalition that was forming. ${ }^{19}$ In the first half of the 1990s, Czech women's civic groups joined and developed supportive networks with foreign and international women's organisations rather than developing lobbyist networks with governmental and party structures within the country or creating permanent collective channels of criticism (e.g. shadow reports commenting on government adherence to binding anti-discrimination and equality documents targeting governmental structures and political parties within the country). ${ }^{20}$

However, this situation changed over time. An important event occurred in

turn of women to the household and family responsibilities. Similar statements from this period included, for example, a claim that women should leave the labour market during periods of growing unemployment in order to make space for men, arguing that men are the 'main breadwinners'. Employers justified paying women lower salaries by citing a 'man's obligation to feed his family' [Hašková 2005].

17 Religious women's organisations do not build coalitions with non-religious women's NGOs. They create their own umbrella organisations, e.g. Clubs of Christian women.

${ }_{18}$ For example, an umbrella organisation of left-wing women's clubs was founded as early as 1992 and there are now more than 70 clubs registered under it. In 1993, the Democratic Alternative, an umbrella organisation, was founded in order 'to create a counterbalance to large left-wing Czech Women's Union, and in order to unify small organisations focusing on women's rights, during the period of legislative changes within after-1989 transformation ... Support to right-wing parties was declared in declaration, which was signed by organisations of the Democratic Alternative' [Marksová-Tominová 1999].

${ }^{19}$ For example, in 1998 the Association for Equal Opportunities was established as an umbrella association of several independent experts and more than twenty women's NGOs 'with different focuses but a similar date of foundation - after 1989', which was clearly stated in its definition. However, recently, owing to development in the NGO scene in the process of EU enlargement (this will be described further on in the article), this rather inactive umbrella organisation also tried to lobby together with Christian women's clubs and the CWU (who are not however a member) for specific issues at the government level.

${ }^{20}$ There was however one important exception. As early as in 1990, the Women's Council was established as an association of women's organisations and initiatives aimed at supporting full compliance with the 'Convention on the Elimination of All Forms of Discrimination Against Women'. However, three years later, the Council dissolved without having achieved any significant successes. 
the form of the Beijing World Conference on Women in 1995. As a result of this conference, the 'Platform for Action' was created, and women's NGOs began to collectively monitor government conformity with the ideas contained in the document. The Czech government used the document when later preparing government documents on complying with the 'Priorities and Procedures of the Government for the Implementation of the Equality of Men and Women' (Priorities...), which have been adopted each year by the cabinet since 1998 as part of the preparation process for EU accession. The documents were evaluated by the European Commission. Later on, they were also critically evaluated by Czech feminist activists in the publication of another version of the report - 'a shadow report' issued in 2004 [see Pavlik 2004].

The situation of women's civic organising in the country in the first half of the 1990s was hugely affected by the change in the political regime, by some effects of the legacy of communism, and by the enormous role that foreign and international donors and feminist activists played in the development of women's civic groups in the region. But the situation described above differs from the current situation of women's civic organising in the region owing to another influential process - EU enlargement.

\section{Women's civic organising during the period of EU Eastern enlargement}

EU accession negotiations started in the CR in 1998. EU accession negotiations had a profound impact on shaping the environment in which women's civic groups now operate in the CR and in other CEE countries. Under the pressure of the preparation for accession to the EU, government bodies were created to focus on the promotion of gender equality, and these bodies become new actors on the scene. In addition, EU equality directives were introduced into the national legislation. The EU moreover highlighted the importance of co-operation between governments and NGOs. All these processes and points were not just emphasised by the EU; government compliance with them was also reported on in annual government reports (Priorities... in the $C R$ ) submitted to the European Commission by all the EU candidate countries, which were then evaluated by the EU as conditions that candidate states were required to meet prior to accession. In effect, the governments of the EU candidate countries were forced to address in some form a number of the issues that women's civic groups in those countries had been raising since the early 1990s:

...the fact is that throughout the nineties there were very, I'd say, active women's organisations that talked about it, but society had absolutely no interest in listening, in accepting it, not at all, and things de facto began happening once talk began to turn to EU accession ... it changed in the moment when harmonisation for EU accession started. ${ }^{21}$

${ }^{21}$ Focus group 1 - an older representative of a large long-term women's NGO with offices in several regions that focuses mainly on work-family issues. 
Many women's civic groups in the EU candidate countries expressed satisfaction with the legitimating power that EU attention brought to some of the issues they had been addressing:

Some journalists were already sensitive to gender issues, these journalists wanted to write about the issues, but their bosses stopped them at that time ... in the situation where talks about the European Union started, they began to be authorised to write about the issues. Everything has been perceived differently since that time. Then our articles and comments started to be published and quoted in newspapers. Certainly, without the pressure from the outside [the EU author's note], who knows where we'd be. ${ }^{22}$

Women's civic groups in the region have used the existence of EU directives on gender equality to bolster their claims, when lobbying the government for policy changes, that their goals are important, and have used the argument that if the EU supports it, the government should support it as well: '...we're going to try that again ... we're going to lobby Parliament, because in our view the Czech Republic is sufficiently under European law in this area - so we have a chance. ${ }^{23}$

At that time, at the end of the 1990s and the beginning of the new millennium, university degree programmes in gender studies were also established at two major Czech universities after many years of lobbying and preparing for their establishment by women's NGOs and people working on gender issues in the academic sphere. Also, projects focusing on gender equality started to be carried out not only by women's NGOs in the country but also within some other organisations, owing to new funding opportunities offering huge amounts of money set aside for this topic and because of increasing gender sensitivity in the country. ${ }^{24}$

All these processes were positive for women and women's civic groups in the country and were brought by EU Eastern enlargement. However, some criticism has also pointed out that many of these processes are more a form of window-dressing, purely formal in character, and have not really been translated into concrete changes (e.g. True [2003]; Pavlík [2004] - both on the CR). Jezerska [2003] (quoted in Einhorn [2005]) pointed out that 'EU accession, while embodying hopes in relation to EU commitment to gender equality through gender mainstreaming, is in practice a process of economic alignment and integration. In this process, concerns not only for gender equality, but also for citizenship and social justice are margin-

${ }^{22}$ A representative of a well-established women's NGO devoted to promoting gender sensitivity and awareness in Czech society, which was founded in the first half of the 1990s in Prague.

${ }^{23}$ Focus group 1 - a middle-aged representative of a women's NGO located in Prague that was established in the first half of the 1990s and focuses mainly on the issue of violence against women.

${ }^{24}$ See analyses of several longitudinal survey data on opinions on gender roles and gender inequalities in the CR in, for example, Hašková [2005]; Hašková, Kř̌́žková, Maříková and Radimská [2003]. 
alized'. Steinhilber [2002] (quoted in Einhorn [2005]) noted that in reality 'neither national governments in the region, nor the EU itself have treated gender as a measure of readiness for accession' because 'it seemed that compliance or noncompliance with the gender norms of EU legislation was likely neither to impede, nor to delay accession for the countries that joined' the EU in 2004.

Even though much of the above-mentioned can clearly be documented in the case of the CR, an environment was ultimately established to promote such changes as introducing and implementing EU equality directives, forming government gender equality bodies, and launching joint activities between the state and women's NGOs. However, the lack of general political will had a negative effect on the newly created environment to promote such changes. This led to gender equality legislation not being enforced, positive action measures and positive discrimination policies not being implemented, and the transformational potential of gender mainstreaming not being activated, ${ }^{25}$ and to the state's window-dressing activities in the following areas: First, government gender equality bodies with limited responsibilities and frequently rotating, uneducated personnel emerged in patches and exhibited a minimum of activity (Linková [2003]; Pavlík [2004] presents, for example, remarkable information about the number of work meetings in these bodies and the absences of key representatives from these meetings). Second, the interactions between the state and NGOs have been abusive and infrequent and could be characterised as a window-dressing tactic.

The period of EU Eastern enlargement also brought about a sharp decrease in the 'development' funding of women's civic groups and increased their formalisation. Formalisation does not mean that women's civic groups became nothing more than empty shells competing for the financial support of quickly diminishing 'development' funding from foreign and international donors operating in the region during the 1990s and the increasing number of governmental project grants and newly available EU project grants. Formalisation means that many women's civic groups were professionalised, that is, they became formally registered entities with office space and staff with the expertise and skills that are required by the state or other donors, and they are supported and recognised by the state or other donors as experts on a particular issue. It also means that they became more project-oriented, in that their activities consist of conducting specific activities with clearly defined objectives, budgets and timelines that the donor sets, or are set in interaction between the donor and the NGO, a relationship that is, however, unequal. And it also means that they became more reform-oriented, in that they work to improve exist-

25 The EU defines gender mainstreaming according to the definition of the Council of Europe: 'Gender mainstreaming is the (re)organisation, improvement, development and evaluation of policy processes. So that a gender equality perspective is incorporated in all policies at all levels and at all stages, by all actors normally involved in policy-making' [Council of Europe 1998: 15]. However, given the guidelines on how to develop and implement this policy strategy, considerable ambiguity in this area remains [e.g. Einhorn 2005; Lorenz-Meyer 2003; Musilová 2000]. 
ing legal or institutional structures step-by-step, or to provide services that could be supported by the state and the EU, which are the main NGOs donors in the era of EU accession. These trends have led to profound changes in terms of the existence, focus, strategies, partnerships, style of work and organisation of the activities of women's civic groups. These processes have also led, on the one hand, to a strengthening of the impact that formalised women's NGOs have on legislative, institutional and societal changes in specific areas of interest, and on the other hand to the marginalisation of women's informal civic groups and women's NGOs that focus on other areas of interest. Paradoxically, the process of EU enlargement, at least currently, has also intensified the orientation of Czech women's NGOs towards Czech state bodies by introducing a new actor onto the scene - gender equality governmental bodies - while EU bodies (with the exception of EU donor agencies) are still perceived by Czech women's NGOs as too removed from them.

\section{The EU Eastern enlargement period - the professionalisation process}

Once governmental equality bodies had been established to co-operate with the non-governmental sector in implementing and enforcing gender equality in the country, many women's NGOs tried to use this situation to gain an influence on legislative and executive processes in the area of their interest. Even though many Czech women's NGOs welcomed the opportunity to interact with the government, many of them were then disappointed and felt they had been abused by governmental bodies, because in addition to their regular activities they were providing expertise to paid state officials without being paid or even acknowledged themselves for this service or for the time devoted to it:

The Government Priorities give the Ministry credit for it all. Also for the six round table discussions going on - the conception that we introduced, its realisation, on which we worked hard for half a year, and for free. They do not even mention the NGOs in the document ... But I still think this is a big accomplishment. That it's being talked about, something is happening, and something is finally likely to change in the legislation - which interests us most at the moment. So now the criminal act is being re-codified ... we have infiltrated those structures almost subversively because they accept us more if our input can somehow become 'their' idea. ${ }^{26}$

However, some women's NGOs and feminist activists have not only succeeded in their efforts to be able to influence legislative and institutional changes in the country but also managed to become recognised as professional experts in a particular area of interest by Czech government equality bodies. They either became official members of the newly created governmental body (advisory only) - the Gov-

${ }^{26}$ A middle-aged representative of a women's NGO located in Prague that was established in the first half of the 1990s and focuses mainly on violence against women. 
ernment Council for Equal Opportunities for Men and Women, ${ }^{27}$ or gained unofficial status as professional experts, to whom, for example, legislative proposals are sent for comments and specifically targeted ministerial grants are given in order to solve specific pre-defined issues. ${ }^{28}$

For those NGOs and figures that became professionalised (i.e. also came to be recognised as experts), the possibility to influence government decisions in a stepby-step manner and to serve as government advisors and the providers of (financially supported) services has opened up. Even though unsuccessful women's NGOs cites their failures when trying to influence legislative and institutional processes and become recognised as experts by state officials owing to the very limited gender sensitivity of politicians and the people occupying the government equality bodies that the NGOs are trying to co-operate with, from an analysis of the successes and failures Czech women's NGOs have experienced in this process it is possible to conclude that alongside the above-cited weakness on the part of state officials and politicians there are also some general structural and cultural factors and factors on the side of women's NGOs that contribute to their success or failure.

Successful professionalisation, and thus the resulting ability to have an impact on decision-making processes, has also depended on: a) whether an organisation is formally established, with an office, a management structure, administrative equipment (such as computers, internet, telephone, fax, etc.), and regularly paid staff; b) an organisation having and activating social networks reaching politicians sensitive to gender issues (especially from a government party); c) the strategic use of certain terms and concepts; d) the ability to propose step-by-step reform-like legislative and institutional changes; and e) being involved in dealing with issues that were stressed by the EU in the EU enlargement process, in compliance with EU equality directives and recommendations. Having an office with equipment, an established management structure, and some regularly paid staff has become important for the ability of NGOs to directly influence legislative and institutional changes because of the long-lasting character of those processes:

Together with Social Democratic Women, we submitted a proposal ... we were successful ... but it took three years... Thus, even though an NGO has a clear idea of what and how to change something, I would say that it would take about three years - at minimum - to do it ... we are

\footnotetext{
${ }^{27}$ It consists of deputy ministers, representatives of women's NGOs and representatives of some other organisations (trade unions, employers and the Czech Statistical Office).

${ }^{28}$ In one case, a young representative of a well-established NGO (Gender Studies, o.p.s. - an unofficial platform for many women's civic groups in the country that was founded at the beginning of the 1990s in Prague in order to promote gender sensitivity and gender equality in the country), who has also been a member of the Social Democratic Party, became the co-ordinator of a newly created department focused on family policies and social work within the Ministry of Labour and Social Affairs. This department has opened up new opportunities for creating effective connections between the women's civic sphere and state institutions, which were lacking previously.
} 
lucky because we have some paid employees and an administrative apparatus, so that we can monitor things to some extent ... If we were on a voluntary basis only, we couldn't do it ... it is necessary to a have a person systematically monitoring the issue, browsing on the internet and downloading things related to the issue, and then working on the issue.... ${ }^{29}$

Another circumstance that helped a women's organisation to gain a greater influence on legislative and institutional changes and to gain recognition as a professional expert body was if it possessed and was able to activate social networks that interfered with politicians and how skilfully they were able to make use of certain key terms. The following quotation relates to the persistent negative perception of feminism and the pro-women orientation in the country, and it also points to the fact that pushing ministries into co-operation with local NGOs (the EU requirement) does not necessarily translate into the existence of co-operation between all ministries and women's NGOs. On the contrary, in the co-operation between the governmental and the non-governmental sectors there has been a tendency to deal with certain problems without including the gender dimension or women's NGOs into the process:

We have mainly focused on domestic violence ... It took really so many years for us - small women's NGOs - to be included, and many would tell you this same story, among experts at least somehow interacting with the government ... Simply because we said we were feminists we were very heavily marginalised. So we then often presented ourselves to others differently ... often in an undetectable form [i.e. in order to at least somehow have an impact on the legislation they underplay the feminist aspect of the issue, gender power relations, and emphasise just their interest in working on the issue as such - author's note] ... We always actively offer co-operation, our know-how ... however, the Ministry of Interior created its own NGO [establishing its distance from women's NGOs - author's note]; it has been financing it for several years. And women's NGOs ... the Ministry considered them to be garbage. And it did not want to co-operate with them ... We had to get through to Špidla [they used their close friendship with a representative of another women's NGO who was a close party-colleague of Špidla, the former premier - author's note], and then, the Ministry of Interior was forced to take us into account ... When it comes to legislative changes, we oppose their ['their' refers to the other NGO - author's note] proposals very often because we maintain a gender-sensitive approach to the issue, and their approach is not gender-sensitive, but we think that without a gender-sensitive approach it is impossible to find the right solutions for the issue. ${ }^{30}$

For women's NGOs focusing on issues that have not been specifically highlighted by the EU in relation to the CR, such as eco-feminism or women's rights in

${ }^{29}$ Focus group 2 - an older representative of a large women's NGO long in existence with offices in several regions that focuses mainly on work-family issues.

30 A middle-aged representative of a women's NGO located in Prague that was established in the first half of the 1990s and focuses mainly on the issue of violence against women. 
relation to childbirth, ${ }^{31}$ and for women's civic groups that are not aiming at step-bystep reform-like changes, the doors of communication between the state and NGOs, the doorway to influencing decision-making processes, and the doorway to obtaining recognition and financial support from the state as acknowledged experts, has remained closed. One example of this is an organisation that had to close its office for a lack of funding owing to its topic (eco-feminism) - 'It is in vain to try to explain the connection between a woman and nature ... I'm isolated' - and because it was at conflict than in co-operation with the government and its focus was not directed at stepby-step reform of existing legal and institutional structures - 'Without radicals, nothing would progress in reality ... If an issue is not defined in terms of conflict, nobody pays real attention to the issue... I see this is the right way'. ${ }^{32}$

Given the abusive and infrequent nature of the interaction between the state and women's NGOs, and owing to the lack of activity on the part of many of the newly established gender equality government bodies, women's NGOs and feminist activists in the country were prompted to write a 'shadow report' on the Government Priorities document with the hope of drawing the attention of the state, the EU and others to its points. However, as discussed elsewhere [Hašková et al. 2004], a number of interviews with European Commission officials have shown such activity is not necessarily welcomed by Commission officials:

We really want to respect the fact that there are issues that if you can't solve them at home, you can't then, say, take an exit strategy [to the EU - author's note] in order to solve problems that can't be solved at home. '... any issue that is not fully allowed to be discussed at the national level cannot be discussed at the EU level. Without the national bodies enabling progress on the issue and without them having an interest in the issue's progress, we can't expect any progress at the multinational level.

This and other expression of reluctance and a lack of concern on the part of the EU that some women's civic groups have experienced has been translated into a growing distrust of the positive impact of EU bodies on the promotion of women's rights and gender equality in the country, especially by those women's civic groups whose focuses have remained at the margins of EU interest: '

... at the end of the day there was not much change in fact ... if you read newspapers constantly, you can see that this has never been a topic that the state would argue about with the EU ... the negotiations were only formal ... they wrote [the government in the Priorities... - author's note] that they have disseminated information [about different approaches to

\footnotetext{
31 The maternal death rate in the Czech Republic is among the lowest in the world when measured with standard instruments, but Czech women still lack a number of rights relating to deciding about the place and the form of childbirth, despite considerable progress in this area in the second half of the 1990s thanks to the activities of NGOs.

32 The NGO was established in Prague in the second half of the 1990s.
} 
childbirth - author's note], will disseminate information, but women know nothing about this. ${ }^{33}$

In sum the process of professionalisation brought about a positive change in that it has helped to strengthen the influence of successfully professionalised women's NGOs on the decision-making processes and has helped them with access to national machineries. Some NGOs took the opportunity given to them by the EU (enlargement) and argued that in the era of the CR's accession to the EU, 'NGOs played a significant role by refusing to make merely formal decisions and make just formal displays of activity. That's where I see them having played a big role. ${ }^{34}$ Together with processes of reform and project orientations, which will be discussed below, the process of professionalisation led to the marginalising of those women's civic groups that were unable or unwilling to professionalise.

\section{The EU Eastern enlargement period - a project-based orientation}

During the EU accession process, the situation of funding for women's civic groups changed. Czech women's civic groups nowadays depend mainly on grant projects for funding, which is time-limited, directed at precisely defined activities, and limited by the topics specified in open calls for project funding. Long-term, flexible and all-inclusive financial support (that could be used not only for specifically defined (project) activities but also for the development of women's civic groups in the region as such) diminished rapidly in the region. As the deadline for accession to the EU neared, donors that had previously considered financial support to women's civic groups in the $\mathrm{CR}$ and other then-EU candidate countries, began to limit the kinds and amounts of funding available to them as they moved their attention away from the EU sphere of influence, usually further East.

Under the changing circumstances of funding opportunities for women's civic groups, the process whereby they became increasingly oriented towards projectbased activity accelerated. This process was perceived as a challenge by women's NGOs in the region:

It changed when we lost the continuous funding from the German foundation. Then we immediately had to begin to search and search for grants, which is an extremely difficult task. This is because when you have a clear vision and structure of what you want to do and you want to carry out a specific activity, it is almost impossible to survive, because grants are always configured a bit differently. The grant has its own character; there is always a definition that

33 A representative of an NGO established in Prague in the second half of the 1990s for the purpose of focusing on health-care issues and parenthood.

34 A young representative of a women's NGO established in the middle of the 1990s focusing on prostitution. 
you have to fit into. This means that you are then required at that moment, even if you have a clear vision of a certain project, to make the project fit the needs of the funding institution. I consider this a serious problem and it will simply become a bigger problem in the future. ${ }^{35}$

State institutions and the European Commission became the new and the most important funding bodies in the region during the EU accession period. They offer funding in the form of calls for projects. The state usually provides short-term smaller grants. Current EU funding differs from what was available before in that it involves much larger budgets. Thus, the availability of large EU funding in the region brought about positive change in the sense that it offered large amounts of money for projects focusing on gender equality, but these same funds also attracted NGOs other than women's organisation to apply for this funding even though some are lacking in any kind of gender expertise. EU funds require extensive partnerships with different social actors and new forms of expertise and resources. Project applicants must also be professionalised, that is, registered entities with office space, qualified staff, and the capacity to manage large projects - qualities that are required by donors:

There's a lot of talk now about the so-called structural funds of the EU, and there I guess the basic problem will be that the structural funds will be somewhat out of reach for women's NGOs, because they just won't have the administrative capacity to be able to obtain that funding and then administer that funding. ${ }^{36}$

There is also another problem associated with the EU structural funds that presents Czech women's NGOs with a difficulty in competing for them. Applicant organisations are required to have a considerable long-term financial resources on their account, a criterion only large and well-established organisations can fulfil, while the majority of women's civic groups are unable to do so, as the last-mentioned representative points out:

What women's organisation can afford that? In each project ... you have to have the money, somehow, at the beginning of the project. And you have to pay for the project. And then, in the future, you get money for the project. That is one problem. ... and then you have to pay some percentage of the total project budget by yourself. That's another problem.

In this situation the question could arise as to whether attracting non-women's NGOs to compete for structural funds combined with the fact that most women's

\footnotetext{
35 A representative of a well-established women's NGO that focuses on raising gender sensitivity and awareness in Czech society and that was founded in the first half of the 1990s in Prague.

${ }^{36}$ Focus group 2 - an older representative of a large women's NGO long in existence with offices in several regions that focuses mainly on work-family issues.
} 
civic groups lack the requirements to be co-ordinators of huge EU funds would lead to the creation of large EU-funded projects, co-ordinated by big professionalised non-women's NGOs, which would then sub-contract tasks within the project to small women's NGOs. If this were the case, women's NGOs would not have the final word on the project designs, activities and dissemination. This would probably result in poorer-quality projects and a reduction of the feminist aspects within the projects. But thus far this has not occurred because there are at least two professionalised women's NGOs that also have the administrative capacity to manage such projects.

Once it became necessary to apply for huge EU partner-demanding project grants several seminars were organised for the second round of applications for structural funds. The seminars were organised by the larger women's NGOs and by non-women's NGOs in order to create working groups to determine the design of project proposals for possible grant applications for structural funds. However, several women's NGOs expressed the feeling that there was reluctance on the part of those seminar participants to speak owing to a fear that their ideas would be stolen by others if voiced. The issue of 'stolen ideas' appeared again in the region during period of NGO project orientation and professionalisation - first in connection with abusive government-NGO relations and second in connection with relations between NGOs. This situation can be attributed to the general under-recognition of women's NGOs and their work in the society, to exploitation of their work by the state, and mainly to the growing competitiveness among women's NGOs: 'Recently, the rivalry between NGOs has become strong in general. ${ }^{\prime 37}$ Competitiveness has increased owing to the reduction of funding bodies for women's civic groups in the region and to the fact that other, non-women's NGOs have begun to deal with issues of gender equality, and also because women's civic groups now need to establish extensive partnerships with women's and other organisations they are unacquainted with and whose work in the area of gender equality and women's rights they are distrustful of owing to quality concerns.

In sum, in the period of EU Eastern enlargement, the EU and the state became the most important NGO donors in the CR, while foreign and international donors that acted in the country during the 1990s left the country as it moved into the EU sphere. This introduced an opportunity to gain large EU funding for gender equality projects, but also ushered in increased competitiveness between different actors dependent on the same donors along with new requirements that women's civic groups professionalise and create extensive partnerships with actors outside the sphere of women's civic groups, some of whom (with or without any gender expertise) began to successfully apply for funding for gender equality projects (with or without women's NGOs as project partners), which sometimes, but not always, produce poor-quality results and have no feminist orientation.

${ }^{37}$ A middle-aged representative of a women's NGO located in Prague that was established in the first half of the 1990s and that focuses mainly on the issue of violence against women. 


\section{The EU Eastern enlargement period - an orientation towards reform}

The professionalisation and the project-based orientation of women's civic groups in the CR proceeded hand in hand with the process of orientation towards reform. An orientation towards reform means that the professionalised and project-based women's NGOs and feminist activists (that became informal government advisors, members of the government advisory bodies on gender equality, the 'tutors' of state officials in gender equality, or project co-ordinators and services providers acting with government or EU funds) work in an area designated by the state and the EU (the donors) and their activities are oriented towards achieving step-by-step reform to improve the existing legal and institutional structures. The relationship between the donors (who are also the decision-making institutions), that is, the EU and the state, and women's civic groups is not equal. The donors decide and select who their expert NGOs are to be and the range of NGO activities they support. Women's NGOs acknowledge the weakness of their position and describe their position as that of the 'third' sector, sometimes even accused of being 'the parasite' sector. ${ }^{38}$ The following two features can be identified as part of the reform-orientation process that affected women's civic groups in the CR in the period of EU accession: 1) acting within an agenda set by the EU (and the state) in order to improve the existing legal and institutional structures; and 2) the marginalisation of those who decide to act differently.

It is clear, therefore, that the donors have the power to delineate the scope of topics, approaches, activities and strategies of those who are dependent on their funding because there are no longer any other important donors in the region (neither the donors of the 1990s, nor public support). But if the state and the EU have become the two most important donors, who is the most important actor in framing the scope of topics, approaches, activities and strategies of women's civic groups in the region? To answer this question it must first be noted that the gender equality agenda of the state was strongly influenced by the EU. However, the state also has a great deal of power over establishing the framework for the topics and activities women's civic groups address. For example, when it comes to the EU structural funds, Czech national agencies (which in an analysis by Marksová-Tominová [2003] were rated as gender-insensitive to gender-unfriendly) distribute the money from EU structural funds to applicants for funding and play an important role in the process of selecting candidates for funding:

I would say that we [women's NGOs] are attractive for the community funds. That has become clear recently because the focus is much more on equal opportunities than before at the European level. But we are not that attractive for the structural funds because within those funds EU money is distributed through governmental agencies. ${ }^{39}$

\footnotetext{
${ }^{38}$ Focus group 1 - several women's NGOs. NGOs began to be designated as 'parasites' under the previous right-wing premier (now the president of the $\mathrm{CR}$ ), also known for his euroscepticism.

39 A young representative of women's programmes at a foundation established in Prague at the beginning of the 1990s that focuses on human rights.
} 
In sum, the reform-orientation (together with project-based orientation and professionalisation) of women's civic groups has resulted in a situation where professionalised, project-oriented women's NGOs act to improve the established institutional and legal structures because the main important donors are now the EU and the state, but it also leads to the marginalisation of those women's civic groups that operate differently. Some specific examples will be presented below.

\section{The EU Eastern enlargement period - closing offices and changing focuses and strategies}

Since there is no tradition of public support for women's groups in the region in the form of participation or philanthropy, and the forms of funding are nowadays aimed at state and especially EU project calls, a particular kind of women's civic groups are being marginalised and are faced with concerns about their ability to survive. These are women's groups that focus on topics and strategies that lie outside mainstream topics and strategies or that are engaged in activities and services of a different scope and character than what is the mainstream scope and character of the grants available to day, which are now defined by the donors, that is, primarily the EU and the state. As a result, some women's civic groups, which were unwilling or unable to change their focus and strategies, have been shut out completely, while other NGOs have moved to become more involved in the issues, activities and strategies that are supported and more or less away from other issues.

An example of an NGO unwilling or unable to adjust is one eco-feminist NGO that focused on local or small-scale activities, consuming little money, which has now had to close its office owing to a lack of funding. Its former representative saw the difficulty of gaining funding for its activities in the 'new era of funding' as lying not only in their topic - eco-feminism - but also and especially in the scope and character of the activities supported: 'They [the donors] want a project for $90000 \mathrm{CZK}$ [3 $000 \mathrm{EURO}$ ], they give it to some agency, the agency charges them $90000 \mathrm{CZK}$ and they are satisfied ... I can't accept that, I can't. I don't even know how to do those [big projects]' ${ }^{40}$ The example of the second case indicated above could be illustrated by an NGO that focused on addressing issues relating to reproductive health while supported by a foreign 'parent' organisation covering all activities. After funding from the 'parent' NGO became unavailable, it changed its focus to equal opportunities in connection to work and family, in correspondence with the thematic focus of available grant resources:

I'd say that at the present time it's evolved in a somewhat different direction than where it was going originally. The initial area was ... reproductive health and caring for children. ... the focus and everything changed... This was relatively difficult and painful ... we began a process of strategic planning ... with all these changes the organisation suddenly shifted in another di-

40 The NGO was established in Prague in the second half of the 1990s. 
rection. So now ... for the purpose of some grant applications we just re-formulated it differently ... we're going to go on to focus on these equal opportunities in connection with the family and the labour market, with regard to benefits, and the equality of men and women in the family. ${ }^{41}$

The departure of foreign and international funding bodies that acted in the region during 1990s and the absence of public support for women's groups has therefore meant that women's civic groups outside the mainstream have had to decide whether to close their offices and maybe get hired by professionalised, project-oriented and reform-oriented NGOs to work on projects designed differently and with a focus on other issues (the case of the head of the eco-feminist NGO) or to change their strategies for attaining their goals, or even to change their goals as such (the case of the NGO that has changed its focus).

The case of the NGO's 'change in focus' is illustrative of the effects of the processes of increasing project-orientation, reform-orientation and professionalisation that were described above. This NGO did not just change the issues it focuses on in order to survive; the changes were much more profound: 1) its entire focus shifted (it broadened the range of topics to include ones that are more acceptable, more mainstream and for which funding exists); 2) its director was exchanged for a 'professional fundraiser'; 3) it now successfully applies for and carries out projects (it had carried out projects even when it had continuous funding though); 4) it has increased the number of its employees and contracted personnel; it has its own office, equipped with computers, telephone, etc.; 5) its long-term representatives do not want to give up their previous agenda but they have recently become reluctant to discuss it - 'until other [more acceptable - author's note] problems are solved'; 6) it eliminated their previous protest and campaign-like activities (protest letters, protest demonstrations in hospitals); 7) within the framework of its previous programme it now concentrates on step-by-step institutional, legislative and societal (education-like) changes only (partly successfully); 8) it has focused on establishing contacts with state officials in its new and its previous areas of interest (still unsuccessfully); 9) it is striving to attain the status of informal government advisor and legislative discussant in the area of its new and its previous interests (still unsuccessfully).

In sum, under the processes of professionalisation, project-orientation and reform-orientation, the changes in the donor situation in the Czech Republic brought about the marginalisation of women's NGOs outside the mainstream in terms of topics, the scope of their activities, and strategies, leading either to the closure of those women's NGOs or to changes in their focus and strategies.

${ }^{41}$ The NGO was established in Prague in the second half of the 1990s. 


\title{
The EU Eastern enlargement period - changing partners
}

The conditions attached to new funding bodies in the region have encouraged not only changes in the focus, scope of activities and strategies of women's NGOs in the region but also changes in their partnerships. The need to form extensive partnerships between disparate organisations and sectors was articulated in the region as one of the requirements for successfully applying for the new, large EU project funds. One such example is a grant from EU funds for a project on the issue of work/life balance. It is co-ordinated by the Czech Women's Union (CWU), a women's NGO that experienced strong opposition from Czech feminist groups during the entire 1990s. However, the structure of this grant is such that the co-ordinator must be a professionalised entity and is required to contract a large number of partner organisations. Thanks to the formalised structure of this co-ordinating NGO, which has a number of permanent employees, additional funding and property resources, and therefore also its potential to successfully apply for and manage such large projects, the CWU was able to contract out tasks to many partner organisations in the academic, state, trade union, business and NGO sectors. Among the partner NGOs contracted to work on specific tasks are even those who had been declaring a strong opposition to the CWU since the beginning of the 1990s, excluding it from other coalitions and umbrella organisations. The result is that women's NGOs in the region have begun to form partnerships with organisations in a variety of areas, focuses and approaches in ways they would never have done before.

This situation can be assessed from two perspectives: It is possible that this new funding situation in the region could serve to mandate co-operation across interests, with the goal of interconnecting different parts of the previously rather disjointed women's NGO scene and broadening responsibility for gender equality beyond just the domain of women's NGOs to society on the whole (employers, trade unions, media, etc). The danger remains, however, that these partnerships have been created as only strategic, temporary, project-based partnerships, that they are not based on any mutual understanding, and thus, as the CWU puts it, without a productively close connection between them:

\begin{abstract}
It was OK when we had a project with three or four organisations ... it was not a problem to divide up our tasks because there was also a good personal relationship among us ... We knew who was good at what, who was an expert in which area ... We applied for ... [name of the EU project - author's note $\backslash$ together with seven partners.... Our application was accepted but it was written there that we have to widen our group of partners ... thus, one partner made a huge campaign to find new partners and then I received an enormous number of offers from organisations that wanted to join the project... there were about sixty of them .... and then we chose thirty partners and with those thirty partners we started the project ... nobody will ever get me to establish such a huge partnership again ... some organisations were just dead-heads... It happened about two or rather three times that we had to change our partners....
\end{abstract}

The experience of managing an EU-funded project shows that there are serious risks involved in organising large projects with a large number partners that do not 
know each other, and especially with partners outside the sphere of women's NGOs. First, there is the problem of having no knowledge about the capacity and the style of work of the partners. Second, in addition to the need that there be a skilled manager to co-ordinate such a huge project, it is also necessary that there be a professionalised NGO to co-ordinate the project - the project co-ordinator must have in place a skilled and equipped, full-time, paid, management apparatus, and it must be an established organisation with large office space, a bank account, and sufficient financial resources to invest into the project in its early stages. This excludes many women's NGOs from becoming large EU project co-ordinators. They are therefore also excluded from being in a position to design the projects, recognised as their coordinators (and experts), and from having a final word in each step of a project's procedures, strategies and the dissemination of its outcome. Third, there is the problem of different approaches to and different levels of understanding about women's issues and basic gender concepts, the problem of using different 'languages' and different approaches, which are broadly appealing or at least acceptable to a greater number of women's and non-women's NGOs. Even though such differences can be mutually enriching for the individual partners, the one experience of such a project had also revealed the many negative effects of those differences.

In sum, huge projects requiring extensive partnerships across different sectors of the society can be confronted with the problems of mutual misunderstandings, unfulfilled expectations, negatively perceived hierarchies, the segmentation of project partners, and a deceleration of the pace of a project's progress. This leads to less satisfaction with the project's outcome and frustrations on the part of the partners involved. In long run, this could lead to lowered expectations about what is to come out of such projects. However, it could also cause organisations to know more about other organisations as partners and thus to better project partner choices in the future.

\section{The EU Eastern enlargement period - informal women's groups}

While the $\mathrm{CR}$ was preparing for EU accession the process of formalising women's NGOs accelerated and came to affect more or less all women's NGOs in the country. But the image of an across-the-board formalisation of women's NGOs in the region must be questioned, because also during the pre-accession period a small, but nonetheless significant, number of small, unregistered, office-less, employees-less, voluntary-based, occasionally active, creative, radical (not reformist) groups oriented towards campaign and protest activities (not project-oriented), operating on small budgets (with resources based mainly on friendships but also obtained from the public through their public activities), and usually staffed with young women, appeared on the women's civic scene (or increased their visibility) in the region. It could be argued that these groups are still in the first stage of development (some women's NGOs that have recently become formalised started out like that) and that they will start to formalise later on. However, there is one important difference between them and similar women's civic groups that started out in the first half of the 1990s: they explicitly reject the formalisation trend, and as its few opponents bear some signs of 
a new social movement. Even though they explicitly criticise formalised women's NGOs for being 'over-formalised', dependent on 'window-dresser', 'abusive' government actors and collaborating with them, and for being more and more distant from the rest of the population by working in their offices on projects targeting issues and activities decided on by the donors, instead of engaging in and supporting grassroots feminist activism, they also have many friends among women's NGOs, who allow them to use their office spaces, printers, and infrastructure for disseminating the materials of informal women's groups. A clear example of this kind of an informal women's group in the CR is a group of anarcha-feminists active on an ad hoc basis; but there are also other examples of women's groups that have appeared when protest activities were being organised, and then disappeared again (e.g. an informal group of women focusing on reproductive health).

In sum, the emergence and existence of informal campaign and protest-oriented women's civic groups operating on an occasional or ad hoc basis and with very small budgets, and supported through solidarity and friendships with established women's NGOs and other sympathetic civil society actors (e.g. anarchists in the case of anarchafeminists) in the region contrasts with the predominant image described above of the processes of formalisation. However, with the formalisation of civil society groups and no tradition of public support for them (in the form of participation as well as financial support) leaves them at the margins of the discussion and activities on women's rights and gender equality in the region.

\section{The EU Eastern enlargement period - the limits in scope}

The EU was the main force behind extending the range of national actors involved in promoting gender equality in the region. Foreign and supranational bodies also supported women's civic groups in the region before the era of EU Eastern enlargement. As early as 1991, women's NGOs in the CR and in other countries of the former Eastern block joined the Network of East-West Women, which supported women's organisations in post-communist countries. They also established the Karat Coalition a network of women's organisations from CEE countries, which acts as a joint lobbying platform at the international level and from the specific perspective of women in the CEE region, a region that has much in common owing to its similar 20th-century history. Somewhat later in the process of EU Eastern enlargement, another important supranational body - the European Women's Lobby (EWL) - became a new, powerful actor on the scene, because with the accession to the EU, women's NGOs from the new member states obtained the right to become a member.

Czech women's NGOs believe in the capacity of the EWL to effectuate change at the EU level: 'The only way in which to influence European legislation is through the European Woman's Lobby'. ${ }^{42}$ 'During the preparations for Beijing +10 , they were able to

${ }^{42}$ Focus group 2 - an older representative of a large women's NGO long in existence with offices in several regions, focused mainly on work-family issues. 
make the EU take all the comments and include them in the document. Thus, they have real power. ${ }^{\prime 3}$ However, Czech women's NGOs also seem united in their opinion that there are also bad sides to the powerful position that the EWL occupies. They point especially to the fact that the EWL's 'position is exclusive and monopolistic'. ${ }^{44}$ Not all of them feel that their interests are represented by the EWL and they do not believe that they will be represented in the future even though the EWL uses the mechanism of a rotating presidency:

Those feminist organisations that have a different approach to prostitution ... they can't co-operate with the EWL and they don't co-operate with it ... there should be more opportunities, more lobbying groups to represent the diversity that exists in reality... ${ }^{\prime} 4$ 'We can discuss the effectiveness of this approach in which one organisation represents everybody, even though it is clear that there are different opinions. It is very easy and comfortable for the EU that they have the only partner for discussions ... This power position is not good. ${ }^{\prime 46}$

There is another reason why Czech NGOs remain sceptical of the EWL, and it derives from their own experience with the EWL. Even though a sense of scepticism prevails, some Czech NGOs became EWL members for the following reasons:

We also signed up for it [membership in the EWL] ... we are a bit sceptical about the organisation, but we want to be members from the practical point of view. It is better to be in than to be out ... one year ago the situation was such that they [the EWL] would admit some organisations we'd almost never heard of before, even though we have been working in the field for ten years. They didn't care; they would take any women ... and this was a big impulse for us to get together and get to the EWL in order to ensure that in the Czech representation of the EWL there would at least be organisations that have been active on these issues for several years ... we didn't want to let happen something that happened in some other countries - that some marginal organisations represent those countries. ${ }^{47}$

This sense of alienation from the EWL may have been reinforced by the fact that it was recognised as a new actor among Czech women's civic groups late in the process of EU Eastern enlargement. In this regard, Czech women's NGOs refer to another supranational organisation that they had joined several years earlier and

${ }^{43}$ Focus group 2 - a middle-aged representative of a women's NGO located in Prague, established in the first half of the 1990s and focused mainly on violence against women.

${ }_{44}$ A representative of a well-established women's NGO focused on raising gender sensitivity and awareness in Czech society that was founded in the first half of the 1990s in Prague.

${ }^{45}$ Focus group 2 - a middle-aged representative of a women's NGO located in Prague, established in the first half of the 1990s and focused mainly on violence against women.

${ }^{46}$ Focus group 2 - a middle-aged representative of a women's NGO located in Prague, established in the first half of the 1990s and focused mainly on violence against women.

${ }^{47}$ A representative of a well-established women's NGO focusing on raising gender sensitivity and awareness in Czech society that was founded in the first half of the 1990s in Prague. 
which was already representing them at the supranational level - the Karat Coalition: 'I think that if Karat had a chance to be in a similar position as the EWL...it would be positive'. ${ }^{8}$ But representatives believe that there is no way of making the 'semi-peripheral', 'Central and Eastern European' Karat Coalition as strong as the 'central', 'core', 'European' EWL. ${ }^{49}$ Czech women's NGOs perceive this situation as a game of power, and they appear to identify more with Karat than the EWL:

We co-operated on establishing a network of women's organisations from Central and Eastern Europe, Karat. We got to know each other quite well during the years of co-operation, and so now we know each other and it is not like a situation in which you don't know your partner organisations. But there is a problem in that there has to be a person who distributes information and collects information... in order for the organisation to be able to continue. But try to find a grant for that [not a project grant but a grant to support the continuation of the lobbying organisation - author's note] ... We [Karat Coalition] have a terrible problem with funding and this leads to a weakening of activities. We wanted to represent the region on different levels - the UN, Europe ... in order to not be eaten by Western Europe ... we have supranational experience, we have contacts and I personally, with my experience, prefer intensive co-operation with organisations from post-socialist countries, because co-operation and mutual understanding is better. But there is a problem - the European women's lobby is an entrenched Western European organisation that is connected to a good source of money [as an 'expert body' of the EU - author's note] and they have the money and we have shit all ... again. $^{50}$

Even though Czech women's NGOs have the experience of lobbying at the supranational level through Karat Coalition, the EWL still seems too far removed from them. They evaluate it positively because of its powerful impact at the supranational level, but it is still too removed in terms of its impact and its concern for the situation in the country.

When it comes to lobbying, networking and influencing policies and legislation, for Czech women's NGOs, it seems more meaningful to concentrate on the national level even though the national level still lacks the political will and understanding to recognise their claims. But at the national level Czech women's NGOs have found their first governmental partners and started to establish lobbying channels, and the national level seems to be closer to them and seems to have a more direct impact on Czech women's lives:

${ }^{48}$ Focus group 2 - a middle-aged representative of a women's NGO located in Prague, established in the first half of the 1990s and focused mainly on violence against women.

${ }^{49}$ See Blagojevic [2004] on relations between the 'core' or 'centre' and the semi-periphery.

50 A representative of a well-established women's NGO focusing on raising gender sensitivity and awareness in Czech society that was founded in the first half of the 1990s in Prague. 
... it is more useful to focus on the Czech Republic than expend our efforts on a big lobby for some directives in Brussels... Now, if I had someone and had to decide whether s/he would lobby here or in Brussels, then I would definitely decide that s/he lobby here - inside the country. ${ }^{\prime 51}$

Czech women's NGOs acknowledge the fact, studied and recognised by many scholars [e.g. Regulska 2002, Frazer 1997, True 2003], that transnational bodies are having an increasing impact on citizenship rights (such as gender equality) in individual nation states in the era of globalisation (and, in relation to recent development in the CEE region, the era of EU enlargement). The fact that women in CEE countries have not yet been recognized as fully participating political actors in these countries led Regulska ([2002] cited in Einhorn [2005]) to ask: 'Will the fact that women have not found significant opportunities in formal, domestic political structures make them more likely to search for alternative ways to act politically beyond the nation-state?' The obstacles that Czech women activists seem to encounter at the national level due to lack of will on the part of Czech politicians and representatives of governmental bodies do not lead them to focus more on lobbying at the supranational level - at least recently and at least at the EU level. This is because of some of the obstacles they have encountered at the EU level and primarily because, for them, the nation state and its bodies still play a crucial role in enforcing gender equality and women's rights in the country. Even though the impact of the EU on the Czech government in the area of implementing gender equality in the country has been huge, it is still the state and its bodies who make the decisions about how to implement and enforce EU equality directives and recommendations, about the specific competences of government equality bodies, and about the level of the enforcement of the gender quality agenda across local-region governmental institutions, etc. (Recently the Czech government rejected the advice of the Czech Government Council on Equal Opportunities for Men and Women - an advisory body that women's NGOs belong to - that it bit to have the European Institute for the Equality of Men and Women based in the Czech Republic). Einhorn [2005] has pointed out that, at least recently, in the short to medium term, the effects of lobbying supranational bodies like the EU or the UN must be seen as complementing rather than supplanting the nation state's role in civic issues such as gender equality and women's issues.

\section{Conclusion}

It can be concluded that there were three major social processes that all had a profound impact on Czech women's civic organisation for the promotion of gender equality and women's rights today. The first major factor was the historical legacy of

\footnotetext{
51 A representative of a well-established women's NGO focused on raising gender sensitivity and awareness in Czech society that was founded in the first half of 1990s in Prague.
} 
the state socialist regime. The state socialist regime promoted women's labour market participation without challenging traditional gender roles (leading to women's socalled double burden), set up quotas for women's political participation without recognising them as fully participating political actors, promoted one women's semistate organisation as the only form of women's organisation, but which women in the region remained unable to relate to, and destroyed civil society and feminist activism in the country. This led to reluctance on the part of society in general to support any kind of 'ism's' from the past or to support any kind of quotas, which were historically discredited, or positive discrimination measures, while also destroying an existing tradition of support for women's civic groups. This same legacy made it easy to gain relative general acceptance of proposals made by women's NGOs oriented towards work-family issues but difficult to gain general acceptance for 'unknown' (and ultimately ridiculed) topics in the country, such as sexual harassment or domestic violence, in the first half of the 1990s. It also meant that in the first half of the 1990s women's civic groups were reluctant to be labelled as 'politically oriented', and women's civic groups could be distinguished by the date of their foundation (before and after 1989). Last but not least, it also meant that in the first half of the 1990s women's civic groups exhibited a lack of knowledge and experience; feminist activists generally lacked expertise in the field of gender equality and women's rights issues, and they did not know how to lobby or proceed to achieve institutional, legislative and social changes, or how to attract the interest of the media and the general population.

The second major factor was the political and socio-economic transformation that occurred after 1989. It was focused mainly on economic aspects and left citizenship rights (such as gender equality) at the margins of political and media interest, and during this transformation there was a huge decline in women's participation in formal politics as quotas were abolished and women's activity instead came be concentrated in civil society groups. In this period many foreign (Western) and international organisations were interested in the development of civil society in the region and gave their support primarily to NGOs, sometimes in the form of longterm financial support for their development, and sometimes as funding for specific projects on topics, approaches, and strategies of change defined by the donors. For women's civic groups this was the only source of funding, but it was a productive source that led to their development in terms of knowledge and organisation. The state was not interested in these groups (unless they provided services), and there was no public support for them. Traditional attitudes to gender roles strengthened and a negative view of the equality agenda and equality bodies predominated, seen as phenomena typical for the previous regime, and this played a role in things during the first half of the 1990s, when the debate moreover focused more on values like free competition and the public and politicians directed their attention to the country's economic problems, rather than taking an interest in equality for men and women; this came later, with the negotiations on the country's accession to the EU. 
The third major impulse was the EU accession period itself, which forced the governments of CEE countries to establish national equality bodies, to accept and implement gender mainstreaming as one of their policy tools, and to start co-operating and communicating with NGOs in the region. This brought about positive changes for women's civic groups in the region, in that some of their claims were heard and some of the channels for making an impact on the decision-making process were slightly opened, even though many of the processes introduced at the decision-making level (pushed by the EU) were more a form of window-dressing and had little impact on the real promotion of gender equality in the country. The slight opening up of decision-making channels to include women's NGOs, along with the changes affecting how women's NGOs are funded (the state and the EU became the most important donors, financing women's NGOs in the form of project grants as foreign and international agencies active in the region throughout the 1990s withdrew) intensified the process of formalisation of women's civic groups in the region, a process that involved their professionalisation and their shift to being project-oriented and reform-oriented. Their professionalisation has led women's civic groups to become formally registered entities, with the office space and qualified staff that donors - the EU and the state - require they have, and as such they allow themselves to be supported and recognised by the donors as experts on a particular issue. Project-orientation means that women's NGOs are engaged in conducting specific activities with clearly defined objectives, budgets and timelines, which are established in the unequal relationship between the donors and NGOs. Reform-orientation means that women's NGOs work to improve existing legal or institutional structures step by step, or provide services that the donors might support. All this brought about profound changes in the existence, focuses, activities, strategies and partnerships of women's civic organisations, which had the power to somewhat dilute the impact of the historical legacy in the region. It broadened the spectrum of actors focusing on gender equality in the region. It also intensified the impact of formalised women's NGOs on legislative and institutional changes on one hand, while it marginalised those women's civic groups whose focus lay outside the mainstream issues, activities and strategies (defined by the EU and the state, influenced by the EU), a problem compounded by the lack of public support for women's civic groups (despite a increase in public interest). Paradoxically, the process of EU enlargement, at least at present, has also led Czech women's NGOs to be oriented more towards national decision-making bodies than EU bodies (with the exception of EU donor agencies), to which some of them even belong. This reflects the fact that even though the EU has been a powerful actor, influencing almost every aspect of women's civic organisation in the country, the nation state remains the most important agent for enforcing gender equality and women's rights in the country. 
HANA HAŠKOVÁ works in the Gender and Sociology Department at the Institute of Sociology of the Academy of Sciences of the Czech Republic. In her work, she focuses on women's civic organising in Central and Eastern Europe, and on the topics of motherhood and childlessness.

\section{References}

Blagojevic, M. 2004. “Creators, Transmitters and Users: Women's Scientific Excellence at the Semi-Periphery of Europe." Pp. 137-145 in Gender and Excellence in the Making. Brussels: European Commission.

Council of Europe 1998. Gender Mainstreaming. Conceptual Framework, Methodology and Mainstreaming. Strasbourg: Council of Europe.

Čermáková, Marie, Hana Hašková, Alena Křížková, Marcela Linková, Hana Maříková and Martina Musilová. 2000. Relations and Changes of Gender Differences in the Czech Society in the 90s. Prague: Institute of Sociology of the Academy of Sciences of the Czech Republic.

Einhorn, B. 1996. "Gender and Citizenship in East Central Europe After the End of State Socialist Policies for Women's 'Emancipation." Pp. 69-86 in Citizenship and Democratic Control in Contemporary Europe, edited by Barbara Einhorn, Mary Kaldor, and Zdeněk Kavan. Cheltenham: Edward Elgar.

Einhorn, B. 2005. "Citizenship, Civil Society and Gender Mainstreaming: Contested Priorities in an Enlarging Europe." Czech Sociological Review 41 (6) - this issue.

Frazer, N. 1997. Justice Interruptus: Critical Reflexions on the "Postsocialist" Condition. New York: Routledge.

Fuszara, M. 2005. "Between Feminism and Catholic Church: Women's Movement in Poland." Czech Sociological Review 41 (6) - this issue.

Gal, S. and G. Kligman. 2000a. The Politics of Gender after Socialism. Princeton: Princeton University Press.

Gal, S. and K. Gail. 2000b. Reproducing Gender: Politics, Publics, and Everyday Life after Socialism. Princeton: Princeton University Press.

Goldman, L. 1996. "To Act Without 'Isms': Women in East Central Europe and Russia." Pp. 35-50 in The Gendered New World Order: Militarism, Development, and the Environment, edited by Jennifer Turpin and Lois Lorentzen. New York: Routledge.

Hann, C. 1996. "Introduction: Political Society and Civil Anthropology." Pp. 1-26 in Civil Society: Challenging Western Models, edited by C. Hann and E. Dunn. London: Routledge.

Haukanes, H. and F. Pine (eds.) 2005. Generations, Kinship and Care. Gendered Provisions of Social Security in Central Eastern Europe. Bergen: University of Bergen.

Hašková, H. 2005. "Gender Roles, Family Policy and Family Behavior: Changing Czech Society in the European Context." Pp. 23-52 in Generations, Kinship and Care. Gendered Provisions of Social Security in Central Eastern Europe, edited by H. Haukanes and F. Pine. Bergen: University of Bergen.

Hašková, H., A. Kř́žzová, D. Lorenz-Meyer and L. Simerská. 2004. “Interrogating Women's Collective Agency in Central and Eastern Europe." Paper presented 2 October 2004 at the international conference Women and Gender in Contemporary Europe. USA: New Jersey: Rutgers University.

Hašková, H., A. Kř́žzová, H. Maříková and R. Radimská (eds.) 2003. Rovné přiležitosti mužủ a žen při slad'ování práce a rodiny? (Equal Opportunities for Men and Women in Work/Life Balance?) Prague: Institute of Sociology, Academy of Sciences of the Czech Republic.

Havelková, H. 2002. Rozdily mezi proní a druhou vlnou ženského (feministického) hnutí II. Část. 
(Differences between the First and Second Waves of the Women's (Feminist) movement. Part II.) Accessed 1 December 2005 at: www.feminet.sk/show.stm?x=13650.

Jezerska, Zuzana. 2003. "Gender Awareness and the National Machineries in the Countries of Central and Eastern Europe." Pp. 167-183 in Mainstreaming Gender, Democratizing the State: Institutional Mechanisms for the Advancement of Women, edited by Shirin M. Rai. Manchester and New York: Manchester University Press for and on behalf of the UN. Quoted in Einhorn, B. 2005. "Citizenship, Civil Society and Gender Mainstreaming: Contested Priorities in an Enlarging Europe“. Czech Sociological Review 41 (6) - this issue.

Kabrhelová, M. 1989. Speech given on 16 June 1989 at the Convention of the Czechoslovak Women's Union.

Kapusta-Pofahl, K., H. Hašková and M. Kolářová. 2005. “Only a Dead Fish Flows with the Stream: Subversive Voices, NGOization and Czech Women's Organizing." The Anthropology of East Europe Review 23 (1): 38-52.

Kay, Rebecca. 2000. Russian Women and Their Organizations: Gender, Discrimination and Grassroots Women's Organizations, 1991-1996. Basingstoke: Macmillan.

Lang, S. 1997. "The NGOization of Feminism." Pp. 101-120 in Transitions, Environments, Translations: Feminisms in International Politics, edited by J. W. Scott, C. Kaplan and D. Keates. New York: Routledge.

Linková, M. 2003. "The Institutional Framework for Equal Opportunities Enforcement." Pp. 31-37 in Sociological Papers 9: Women's Civic and Political Participation in the Czech Republic and the Role of European Union Gender Equality and Accession Policies, edited by H. Hašková and A. Křížková. Prague: Institute of Sociology, Academy of Sciences of the Czech Republic.

Lorenz-Meyer, D. 2003. "Policy Initiatives and Tools to Promote the Participation of Women and Gender Equality in the Process of the Czech Republic's Accession to the European Union." Pp. 59-85 in Sociological Papers 9: Women's Civic and Political Participation in the Czech Republic and the Role of European Union Gender Equality and Accession Policies, edited by H. Hašková and A. Kř́žzová. Prague: Institute of Sociology, Academy of Sciences.

Marksová-Tominová, M. 1999. Formy ženských aktivit. (Forms of Women's Activities) Prague: Gender Studies, o.p.s.

Marksová-Tominová, M. 2003. Gender Issues within EU Accession: Situation in the Czech Republic. Brussels: WIDE.

Musilová, M. 2000. “Gender Mainstreaming." Gender, rovné přiležitosti, výzkum 1 (4): 7-9.

Osvaldová, B. 2004. Česká média a feminismus. (The Czech Media and Feminism) Prague: Libri, Slon.

Pavlík, P. (ed). 2004. Stínová zpráva v oblasti rovného zacházení a rovných přiležitostí žen a mužũ. (Shadow Report on Equality and Equal Opportunities for Women and Men) Prague: Gender Studies, o.p.s.

Potůček, M. 1997. Nejen trh. (More than Just the Market) Prague: Slon.

Prečan, V., B. Císařovská, M. Drápala and J. Vančura. 1997. Charta 77 očima současniků - po dvaceti letech. (Charter 77 in the Eyes of Contemporaries) Prague: Doplněk a Ústav pro soudobé dějiny AV ČR.

Rai, Shirin M. 2004. “Gendering Global Governance." International Feminist Journal of Politics 6 (4): 579-602.

Rakušanová, P. 2003. "Hnutí za demokracii." (The Movement for Democracy) Unpublished paper. Prague: Sociologický ústav AV ČR.

Regulska, J. 2002. “Women's Agency and Supranational Political Spaces: The European Union and Eastern Enlargement." A paper presented at the Annual Meeting of the American Association of Geographers, Los Angeles, March 20-24, quoted in B. Einhorn. 2005. "Citizenship, Civil Society and Gender Mainstreaming: Contested Priorities in an Enlarging Europe". Czech Sociological Review 41 (6) - this issue. 
Sampson, S. 1996. "The Social Life of Projects: Importing Civil Society to Albania." Pp. 121-143 in Civil Society: Challenging Western Models, edited by E. Dunn. London, New York: Routledge.

Sloat, A. 2004a. Legislating for Equality: The Implementation of the EU Equality Acquis in Central and Eastern Europe. Jean Monet Working Papers 08/04. New York: New York School of Law.

Sloat, A. 2004b. "Where Are the Women? Female Political Visibility in EU Accession States." Pp. 45-58 in Transitions XLIV-1, edited by J. Heinen and S. Portet. Geneva: European Institute at the University of Geneva ULB.

Sloat, A. 2005. “The Rebirth of Civil Society: The Growth of Women's NGOs in Central and Eastern Europe." European Journal of Women's Studies 12: 437-452.

Steinhilber, Silke. 2002. "Women's Rights and Gender Equality in the EU Enlargement. An Opportunity for Progress." A WIDE (Network Women in Development Europe) Briefing Paper, October 2002, quoted in Einhorn, B. 2005. "Citizenship, Civil Society and Gender Mainstreaming: Contested Priorities in an Enlarging Europe“. Czech Sociological Review 41 (6) - this issue.

True, Jacqui 2003. Gender, Globalization and Postsocialism: the Czech Republic after Communism. New York, Chichester: Columbia University Press.

Uhrová, E. 1994. "Kam kráčely feministky?" (Where Were the Feminists Heading?) Pp. 17-25 in Alty a soprány. Prague: Gender Studies Centre, o.p.s. 